\title{
EFFECT OF SURFACE AND SUBSURFACE TRICKLE IRRIGATION ON YIELD AND WATER USE EFFICIENCY OF TOMATO CROP UNDER DEFICIT IRRIGATION CONDITIONS
}

\author{
A. N. Al-Mansor*1, A. M. El-Gindy ${ }^{2}$, M. M. Hegazi ${ }^{2}$, \\ K. F. El-Bagoury ${ }^{3}$ and S. A. Abd-El Hady ${ }^{4}$.
}

\section{ABSTRACT}

The aim of this study to compare the effect of full irrigation and deficit irrigation, using surface and subsurface trickle irrigation on yield of tomato (Solanum lycopersicum. L.) and the irrigation water use efficiency. A field experiment was carried out on a clayey soil at the Experimental Farm of Faculty of Agriculture, Ain Shames University at Shoubra El Khaymah, Qalyubia Governorate, Egypt. The daily crop water requirement for tomato was calculated by Penman-Monteith equation. The experiment was consisted of four irrigation water levels (T1:100\%ET $T_{c}, T 2: 85 \% E T_{c}, T 3: 70 \% E T_{c}$ and $T 4: 55 \% E T_{c}$ ) accompanied with two kinds of trickle irrigation ( $S$ : surface and SS: subsurface). Deficit irrigation was applied during the whole growing season. The results showed that highest fruit yield (71.88 $\left.\mathrm{tha}^{-1}\right)$ was recorded for T1 under subsurface trickle irrigation (SSTI) while the lowest fruit yield (45.77 $\mathrm{tha}^{-1}$ ) was recorded for T4 under surface trickle irrigation (STI). The highest value for irrigation water use efficiency (IWUE) was found to be $18.80 \mathrm{~kg} \mathrm{~m}^{-3}$ for the T4 under SSTI treatment. Finally it has been concluded that under conditions of water scarcity, especially in the Arab region, which suffers from water scarcity, can be used subsurface trickle irrigation technologies together with deficit irrigation strategies to improve irrigation water use efficiency and tomato yield under open field condition.

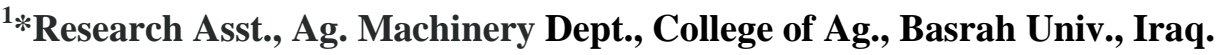

${ }^{2}$ Prof. Emeritus, Ag. Eng. Dept., Fac. of Ag. Ain Shams Univ.

${ }^{3}$ Associate Prof., Ag. Eng. Dept., Fac. of Ag. Ain Shams Univ.

${ }^{4}$ Associate Prof., Hort. Dept., Fac. of Ag. Ain Shams Univ.
} 


\section{INTRODUCTION}

W ater scarcity is an increasingly important issue in many parts of the world. This is especially the case in arid regions of Arab countries to frequent droughts and where restricted supply of good quality water is the most important factor limiting crop production. Insufficient water supply for irrigation will be the norm rather than the exception, and irrigation management will shift from emphasizing production per unit area towards maximizing the production per unit of water consumed (the water productivity) (Fereres and Soriano, 2007). According to Perry et al. (2009), switching from flood or furrow to low-pressure sprinkler systems reduces water use by an estimated $30 \%$, while switching to trickle irrigation typically cuts water use by half. Often the terms drip irrigation and trickle irrigation are considered synonymous (ASAE, 2006 and Simonne et al., 2012). In areas with dry and hot climates, trickle irrigation has improved WUE mainly by reducing runoff and evapotranspiration losses (Jones, 2004 and Bhattarai et al., 2008). With the trickle irrigation systems, water and nutrients can be applied directly to the crop at the root level, having positive effects on yield and water savings and increasing the irrigation performance (Simonne et al., 2012). It has been found that subsurface trickle irrigation reduced evaporation from the soil and increased the wetted soil volume and surface area more than surface systems allowing a deeper rooting pattern (Oliveira et al., 1996 and Phene, 1995). Machado et al. (2003) indicated that subsurface trickle irrigation for tomatoes can contribute to increase the commercial production without affecting fruit quality. Full irrigation is the practice of applying the amount of water to a crop equal to that removed from the field by evapotranspiration throughout the growing season. Full irrigation is considered a luxury use of water that can be reduced with minor or no effect on profitable yield (Kang and Zhang, 2004). According to Fereres and Soriano (2007), there is needed to optimize water use in order to maximize crop yields under water deficit conditions. One of the means to improve water use efficiency is deficit irrigation (Topcu et al., 2007). Deficit irrigation has been practiced in different parts of the world (English and Raja, 1996; Oktem et al., 2003; Karam et al., 2005 and 
Ali et al., 2007). The goal of deficit irrigation is to increase crop water use efficiency (WUE) by reducing the amount of water applied (Kirda, 2002). According to Hassan and Abuarab (2013), it is possible to save water improving its use efficiency in processing tomato to achieve adequate fruit yield. Total crop water requirements for tomato ranges from 400 to $800 \mathrm{~mm}$ from emergence/transplanting to harvest, depending on climate, plant type, soil, irrigation and crop management (Battilani et al., 2012). The tomato plant requires significant quantities of water, but not in excess, since tomato roots will not function under water-logged conditions (Benton, 2008). Hartz and Hanson (2009) indicated that tomatoes can tolerate a moderate degree of stress. Tomato plants are sensitive to water stress and show high correlation between evapotranspir-ation (ET) and crop yield (Nuruddin et al., 2003). The amount of water available to the tomato plant affects both fruit yield and quality (Benton, 2008). According to Shahein et al. (2012), it is possible to save water, improving its use efficiency in processing tomato at a low rate $(80 \% \mathrm{ETc})$, to achieve adequate fruit yield, minimizing fruit losses and maintaining high fruit quality levels.

The specific objectives of this study:

1- To determine the effect of water deficit (as quantified by different irrigation levels) on tomato yields.

2- To determine the optimum irrigation water use efficiency for the tomatoes crop.

3- To establish optimal water management strategies for tomato for the purpose of achieving more WP in limited water.

4- Comparison surface and sub-surface trickle irrigation under different irrigation level, and their interaction.

\section{MATERIALS AND METHODS}

\subsection{Location and Plant Materials:}

The experiment was carried out under open field conditions at Experimental Station, Faculty of Agriculture, Ain Shams University, at Shoubra El Khaymah, Qalyubia Governorate, Egypt (latitude $30^{\circ} .12 \mathrm{~N}$, and longitude $31^{\circ} .24 \mathrm{E}$, and mean altitude $26 \mathrm{~m}$ above sea level). Some physical properties of the soil are given in (Table 1). Irrigation water has 
been obtained from Nile river (located in the experimental area), with $\mathrm{pH}$ 7.2 and an average electrical conductivity of $0.63 \mathrm{dS} / \mathrm{m}$. While, soil $\mathrm{pH}$ 6.84 and EC $2.64 \mathrm{dS} / \mathrm{m}$. The cultivar super red hybrid of tomato (Solanum lycopersicum. L.) was used for this experiment. Seedlings were transplanted at four-leaf stage (after 35 days from seed sowing) on 10 October, 2013 in a single plot. The plot consists of 4 rows $(4.8 \times 12$ $\mathrm{m})$. Rows were $120 \mathrm{~cm}$ apart with $60 \mathrm{~cm}$ between plants within the row on flat beds with $1 \mathrm{~m}$ bed centers giving a plant population of 13888 plants per hectare. The plants were provided with optimal growing conditions and all the necessary requirements according to the Agriculture Ministry recommendation of the experimental regions. Harvest-ripe fruits were manually picked and weighed, started on 15 February, 2014 and continued until the end of experiment. The middle four rows in each subplot were harvested by hand to determine tomato yield ( $\mathrm{t} / \mathrm{ha})$, fruit number $/ \mathrm{m}^{2}$, fruit weight $(\mathrm{g})$.

\section{Table 1: Some physical properties of soil}

\begin{tabular}{|c|c|c|c|c|c|c|c|}
\hline \multirow{2}{*}{$\begin{array}{l}\text { Soil } \\
\text { Depth } \\
\mathrm{cm}\end{array}$} & \multirow{2}{*}{ Texture } & \multicolumn{3}{|c|}{ Soil particle distribution $\%$} & \multirow{2}{*}{$\begin{array}{c}\text { F.C. } \% \\
\theta \text { at33 kPa }\end{array}$} & \multirow{2}{*}{$\begin{array}{c}\text { P.W.P.\% } \\
\theta \text { at } 1500 \mathrm{kPa}\end{array}$} & \multirow{2}{*}{$\begin{array}{l}\text { B.d. } \\
\mathrm{g} \mathrm{cm}^{-3}\end{array}$} \\
\hline & & Sand & Silt & Clay & & & \\
\hline $0-30$ & CL. & 24 & 36 & 40 & 31.05 & 14.81 & 1.32 \\
\hline $30-60$ & CL. & 27 & 32 & 41 & 32.71 & 17.68 & 1.34 \\
\hline
\end{tabular}

F.C. $=$ field capacity, P.W.P.= permanent wilting point, were determined as percentage in weight, B.d. = Bulk density and CL. $=$ clay.

\subsection{Experimental Design and Treatments:}

Experimental designs illustrated at (Table 2) where, experiments were laid out in a Split Plot Design (SPD) having four replications. In this experiment, the subplot treatment at different levels of irrigation and main plot treatment at two trickle irrigation systems (surface and subsurface) were utilized. The experiment consisted of four blocks (replicates) each subdivided into eight plots making up a total of 32 plots (16 with subsurface trickle irrigation and 16 with surface trickle irrigation). Each of the plots (treatments) per block comprised single beds $(1.25 \mathrm{~m} * 6.0 \mathrm{~m})$, with an area of $7.5 \mathrm{~m}^{2}$ per plot. 
Table 2: Experimental designs

\begin{tabular}{|c|c|c|c|c|c|c|c|c|}
\hline \multirow{2}{*}{$\begin{array}{c}\text { Exp. } \\
\text { Treat. }\end{array}$} & \multicolumn{6}{|c|}{ Trickle irrigation system } \\
\cline { 2 - 8 } & \multicolumn{4}{|c|}{ Surface trickle irrigation (S) } & \multicolumn{4}{|c|}{ Subsurface trickle irrigation (SS) } \\
\cline { 2 - 8 } & $\mathrm{T} 1$ & $\mathrm{~T} 2$ & $\mathrm{~T} 3$ & $\mathrm{~T} 4$ & $\mathrm{~T} 1$ & $\mathrm{~T} 2$ & $\mathrm{~T} 3$ & $\mathrm{~T} 4$ \\
\hline
\end{tabular}

\subsection{Trickle Irrigation Components:}

The used irrigation system was constructed and installed in the field before tomato transplanting. Irrigation networks include the following components are: 1) Control head: It was located at the water source supply. It consists of centrifugal pump 2"/2", driven by electric engine (pump discharge of $20 \mathrm{~m}^{3} / \mathrm{h}$ and $26 \mathrm{~m}$ lift), screen filter 2" (120 mesh), back flow prevention device, pressure regulator, pressure gauges, flowmeter, control valves and chemical injection; 2) Main line: PVC pipes of $50 \mathrm{~mm}$ in diameter to convey the water from the source to the manifolds; 3) Manifold lines: PVC pipes of $50 \mathrm{~mm}$ in diameter were connected to the main line through control valves 1.5"; 5) Lateral lines: PE tubes of 16 $\mathrm{mm}$ in diameter were connected to the manifolds through beginnings stalled on manifolds lines; 6) Emitters: These emitters built in PE tubes $16 \mathrm{~mm}$, (emitter discharge of $41 \mathrm{~h}^{-1}$ at Operating pressure $1 \mathrm{~atm}$ and 30 $\mathrm{cm}$ spacing in-between), for the subsurface trickle irrigated plots, trickle lines were installed to a depth of $20 \mathrm{~cm}$. Plants were transplanted in single rows, with plants spaced $0.6 \mathrm{~m}$ within the rows. The field was irrigated immediately after transplantation to establish a good root-to-soil contact. After stand establishment on the 10 of October 2013, the first irrigation $(11 \mathrm{~mm})$ was applied to all the treatment plots to stabilize the soil water content in effective root depth. The irrigation water was supplied every four days. One lateral line was used for two plot on same line where divided to half surface and subsurface trickle irrigation.

\subsection{Irrigation Treatments:}

Four water application rates were applied for irrigating tomatoes crop; i.e. irrigation at $(100,85,70$ and 55\%) of reference crop evapotranspiration $\left(\mathrm{ET}_{\mathrm{c}}\right)$ by Penman-Monteith which has now become the standard for estimating reference crop evapotranspiration (Smith and Steduto, 2012). The climatic data such as air temperature, air humidity, rainfall, wind speed and sunshine hours. The mean data of 2008-2012 periods (5 years) was used for estimation of $\mathrm{ET}_{\mathrm{o}}$ and water use. 
Maximum temperatures during the growing period (October-March) ranged from 18 to $34^{\circ} \mathrm{C}$, minimum temperature ranged from 10 to $22^{\circ} \mathrm{C}$. Total rainfall was negligible in all years $(<20 \mathrm{~mm})$. The crop evapotranspiration (ETc) was estimated for daily time step by using reference evapotranspiration $\left(\mathrm{ET}_{\mathrm{o}}\right)$ combined with a tomato crop coefficient (Kc). Crop coefficients vary between crops and crop growth stages. In this study the crop growth was divided into four growth stages and they were as follows (Allen et al., 1998): Initial stage; Developmental stage; Mid-stage and Late-season stage (Table 3).

$\mathrm{ETc}=\mathrm{ET}_{\mathrm{o}} \times \mathrm{Kc}$

Seasonal irrigation requirements were estimated. The seasonal irrigation water applied for treatments (T1, T2, T3, T4) were $(453,397,339,280)$ $\mathrm{mm} / \mathrm{season}$ respectively. For the design of localized irrigation systems by following equation and as tabulated in (Table 3):

$\mathrm{ET}_{\text {crop-loc }}=\mathrm{ET}_{\mathrm{o}} \times \mathrm{Kc} \times \mathrm{Kr}$

Where:

$\mathrm{ET}_{\text {crop-loc= }}$ crop evapotranspiration localized irrigation systems,

ETo $=$ Reference crop evapotranspiration using the Penman-Monteith method, $\mathrm{Kc}=$ Crop coefficient, and $\mathrm{Kr}=$ Ground cover reduction factor Andreas (2002) provides the reduction factors suggested by various researchers in order to account for the reduction in evapotranspiration in this study values of $K_{r}$ suggested by (Keller and Karmeli, 1975).

Actual ETc or adjusted ETc, $\left(\mathrm{ETc}_{\mathrm{adj}}\right)$ was calculated by multiplying ETc by stress coefficient (Ks) as described in the following equation (Allen et al., 1998):

$\mathrm{ETc}_{\mathrm{adj}}=\mathrm{ETc} \times \mathrm{Ks}$

Where: Ks is a dimensionless transpiration reduction factor depends on available soil water and rages from 0 (severe stress) to 1 (no stress), and $\mathrm{ETc}_{\text {adj }}$ is actual crop evapotranspiration $\left(\mathrm{mm} \mathrm{day}^{-1}\right)$ when crop is under water stress. The Ks was determined for the four treatments during the growing season and was calculated by the procedure described in (Allen et al. 1998) for each day. The Ks was calculated as:

$K s=(T A W-D r) /(T A W-R A W)$ 
Where: Dr is root zone depletion (mm), TAW is total available soil water in the root zone $(\mathrm{mm})$ and RAW is readily available soil water in the root zone $(\mathrm{mm})$.

$\mathrm{IRn}=$ ETcrop.. loc $-(\mathrm{Pe}+\mathrm{Ge}+\mathrm{Wb})+\mathrm{LR}$

Where:

$\mathrm{IRn}=$ Net irrigation requirement $(\mathrm{mm}), \mathrm{P}_{\mathrm{e}}=$ Effective dependable rainfall $(\mathrm{mm}), \mathrm{G}_{\mathrm{e}}=$ Groundwater contribution from water table $(\mathrm{mm})$ according to Allen et al. (1998) Capillary rise can normally be assumed to be zero when the water table is more than about $1 \mathrm{~m}$ below the bottom of the root zone, $\mathrm{Wb}=$ Water stored in the soil at the beginning of each period $(\mathrm{mm})$ the contribution of water stored in the soil is considered negligible, and $\mathrm{LR}=$ Leaching requirement $(\mathrm{mm})$.

Amount of water required for the leaching of salts, $\mathrm{mm}=$ LRt $\mathrm{x}(\mathrm{IRn} / \mathrm{Ei})$ where: $\mathrm{LRt}=$ leaching requirement ratio under trickle irrigation $=$ $\mathrm{EC}_{\mathrm{w}} /(2 \times \max \mathrm{ECe})$ where $\mathrm{EC}_{\mathrm{w}}=$ electrical conductivity of irrigation water $(\mathrm{ds} / \mathrm{m})$; max $\mathrm{ECe}=$ electrical conductivity of saturated soil extract that will reduce the crop yield to zero $(\mathrm{dS} / \mathrm{m})$.

Gross irrigation requirement (IRg) $[\mathrm{mm} /$ period] is the net irrigation requirement (IRn) of the crop plus the operating losses of the system:

$\mathrm{IRg}=\mathrm{IRn} / \mathrm{Ei}$

Where:

$\mathrm{IRg}=$ Gross irrigation requirements, $\mathrm{mm} /$ day, and $\mathrm{Ei}=$ Irrigation efficiency $=\mathrm{Ea} \times \mathrm{EU}$, where: $\mathrm{Ea}=(\mathrm{Vs} / \mathrm{Va}) \times 100$, where: Vs $=$ Average water stored in root zone; $\mathrm{Va}=$ Average water applied; $\mathrm{EU}=$ Coefficient reflecting the uniformity of application $=(\mathrm{qm} / \mathrm{qa}) \times 100$, where: $\mathrm{qm}=$ the average flow rate of the emitters in the lowest quartile, $(1 / \mathrm{h})$; and qa $=$ the average flow rate of all emitters under test, $(1 / \mathrm{h})$.

\subsection{Soil Water Content:}

For determining soil water content by the gravimetric method $(\theta g)$, the weight of wet and dry soil has to be known. Samples were taken with a 4 $\mathrm{cm}$ auger from the middle row of every plot after transplanting and at three days after irrigation during initial stage, development, mid-season and at harvest. Each plot was sampled every $15 \mathrm{~cm}$ to a depth of $60 \mathrm{~cm}$, at eight sites perpendicular to the trickle line at distances of $15 \mathrm{~cm}$ from the line .After the sampling, the wet mass of the soil was immediately 
determined. Therefore, soil samples were dried for $48 \mathrm{~h}$ at $105^{\circ} \mathrm{C}$ and $\theta \mathrm{g}$ calculated. Undisturbed soil samples were taken at the beginning of the experiment in order to calculate the bulk density which was used for determining volumetric $\left(\theta_{\mathrm{v}}\right)$ soil water content. From soil water content calculated fraction available water depleted $\left(f_{\mathrm{d}}\right)$ :

$f d=((\theta f c-\theta v) /(\theta f c-\theta w p))$

Where: $\theta_{f c}=$ field capacity, $\theta_{w p}=$ permanent wilting point, and $\theta_{v}=$ volumetric soil water content.

Table 1: Estimation of total irrigation requirements for tomato crop per season.

\begin{tabular}{|c|c|c|c|c|}
\hline \multirow{3}{*}{ Items } & \multicolumn{4}{|c|}{ Growth stages of tomato } \\
\hline & Int. & Dev. & Mid & Late \\
\hline & Oct.- Nov. & Nov.-Dec. & Dec.- Feb. & Feb. -Mar. \\
\hline No. of days/ stage & 25 & 35 & 65 & 30 \\
\hline ETo (mm/day) & 4.78 & 3.23 & 2.93 & 4.29 \\
\hline Crop coefficient, Kc & 0.6 & 0.88 & 1.15 & 0.9 \\
\hline Reduction factor, $\mathrm{Kr}, \%$ & 0.24 & 0.7 & 0.82 & 0.9 \\
\hline Emission uniformity, EU & 0.9 & 0.9 & 0.9 & 0.9 \\
\hline Application efficiency Ea, & 0.91 & 0.91 & 0.91 & 0.91 \\
\hline $\mathrm{LR}, \mathrm{mm} /$ day & 0.07 & 0.16 & 0.30 & 0.35 \\
\hline $\mathrm{R}, \mathrm{mm}$ & 0 & 0 & 0 & 0 \\
\hline IRg, $\left(\mathrm{m}^{3} \mathrm{ha}^{-1} /\right.$ stage $)$ & 331 & 572 & 2423 & 1209 \\
\hline IRg, $\left(\mathrm{m}^{3} \mathrm{ha}^{-1} /\right.$ season $)$ & \multicolumn{4}{|c|}{4535} \\
\hline
\end{tabular}

$\mathrm{R}=$ water received by plant from sources other than irrigation, $\mathrm{mm}$ (for example rainfall); IRg = Gross irrigation.

\subsection{Yield Reductions and Water Saving Determination:}

The reductions in the total fruit yield and water saving was calculated using the following equations as described by (Ismail, 2010):

Reduction in fruit yield $=100-($ yield of T4, T3 or T2/T1 x 100)

Water saving $=100$ - (water consumption of T4, T3 or T2/T1 x 100)--(9)

Where: $\mathrm{T} 1=$ a full irrigation water requirement (control treatment).

\subsection{Fruit Yield and Water Use Efficiency:}

The values for fruit yield (kg/plant) and fruit number per plant are the means of eight plants per treatment. Individual fruit weight was calculated from 10 randomly chosen fruits per treatment at each harvest. Number of fruit per plant is the means of fruits of eight plants per treatment. Irrigation water use efficiency (IWUE) was determined by 
taking the ratio of the marketable yields $\left(\mathrm{kg} \mathrm{ha}^{-1}\right)$ and the total seasonal irrigation volume applied per ha $\left(\mathrm{m}^{3} \mathrm{ha}^{-1}\right)$. It was expressed as $\mathrm{kg} \mathrm{m}^{-3}$ (Howell, 2002).

\subsection{Tomato Quantity Parameters:}

Yield of the tomato plants was determined in terms of number of fruits/plant, mass of individual fruits, yield per plant and total yield ( $t / h a)$. Marketable and total fruit yield per hectare was worked out with the help of fruit yield per plot by using the following formula:

Yield $=($ weight of fruit $\times 10000) /($ plot area $\times 1000)$

Where: Yield, t/ha.

\subsection{Statistical Analysis:}

Statistical analysis was performed on data. In experimental design models, the blocks were considered random effects while the irrigation types and the moisture levels (treatments) were fixed effects parameters. Statistical analyses were performed using SAS. Analysis of fruit yield, fruit quality and irrigation parameter were also conducted. Differences at $\mathrm{P}<0.05$ were considered statistically significant (Gomez and Gomez, 1984).

\section{RESULTS AND DISCUSSIONS}

\subsection{Soil Moisture Content:}

The average soil water content for two layers in the soil profile at (0-30, $30-60 \mathrm{~cm}$ ) each layer is an average value of two readings from two sub layers. Figure (1) shows the average soil moisture content values as percentage in weight under different irrigation treatments for two types of irrigation systems STI and SSTI. Soil water content readings started after transplanting until the end of the season, the average of readings for each stage of crop growth at transplanting (initial stage), development, mid-season and harvest period of the tomato crop. Moisture was directly related to the amount of water applied at full or deficit-irrigated treatments and irrigation systems. Moisture in the soil profile initially showed higher moisture content in all the treatments due to the irrigation amount applied before transplanting to replenish the soil profile to field capacity and the all treatments at initial stage receive same quantity of water $\left(100 \%\right.$ of $\mathrm{ET}_{\mathrm{c}}$ ) for 15 day after transplanting. Soil moisture content in root zone area for initial stage was averaged as $26.7 \%$ and $28.2 \%$, 
respectively, for STI and SSTI as well as fraction of depletion (p) was averaged as $33 \%$ and $23 \%$, respectively. The soil water depletion fraction for no-stress $(\mathrm{p})$ is the fraction of the total available soil water that a crop can extract from its root zone without experiencing water stress. The fraction for tomato crop 40\% (Allen et al., 1998). The results show for all irrigation treatments significant differences were also observed between the soil moisture content of the subsurface irrigated plots and those irrigated with the surface trickle system during the development, midseason and harvest periods. SSTI had higher value of soil moisture content and the lowest percentage depletion than STI's. This is due to reduce evaporation from soil surface by setting drip line under soil surface this result is consistent with (Douh et al., 2013). Subsurface trickle irrigation minimizes the evaporative loss. Also this is in agreement with EI-Awady et al. (2003) where reported that, evaporation decreased with increasing trickle line depth and evapotranspiration from sub-surface trickle irrigation could be reduced to $40 \%$ when the trickle line is buried at a depth of $15 \mathrm{~cm}$ compared with irrigation from surface trickle line, with sorghum crop. The soil moisture content under full irrigation T1 (100\% ETc) was significantly higher than under deficit treatments for both irrigation systems. Soil water content data may help in explaining the severity of water stress among treatments. Figure 1 illustrates soil water content for the root zone along with field capacity (FC), permanent welting point (PWP), total available water (TAW) and readily available water (RAW).
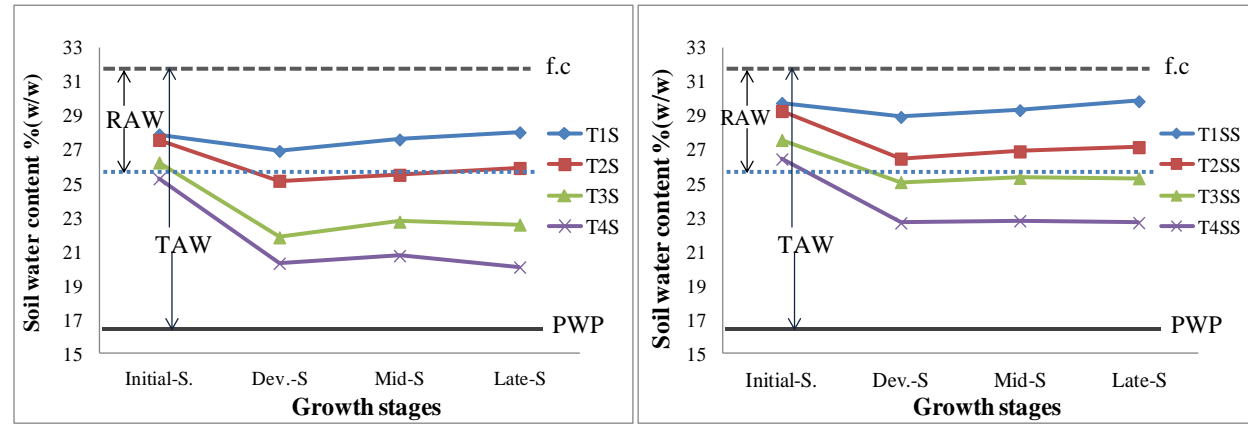

Fig. 1: Average soil moisture content values as percentage in weight under different irrigation treatments for STI and SSTI systems during the growth stages of tomato crop. 
For treatments (T1S, T1SS and T2SS) the soil water contents were always higher than RAW for whole growth stages, but under treatments (T4S, T3S and T4SS) soil water content were near (PWP) for whole growth stages except initial stage. The soil water content for (T2S and T3SS) was near the (RAW) line without any serious water stress. These soil water content readings were in agreement with the crop stress coefficient values, which were less than one in the (T4S, T3S and T4SS). These results indicate that using only $55 \%$ of ETc under two systems of trickle irrigation and $70 \%$ of ETc under surface trickle irrigation for tomato production will result in a severe water stress, lower quantity of yield and may shorten the plant life.

\subsection{Surface and Sub-Surface Trickle Irrigation and Tomato Yield:}

Data are presented in Figure (2) and Table (4) showed that the tomatoes yield was higher using subsurface trickle irrigation compared to surface trickle irrigation. The mean of tomato yields showed significant difference between surface and subsurface trickle irrigation where was 58.63 and $62.65 \mathrm{t} \mathrm{ha}^{-1}$, respectively. The results revealed, the average of tomato yield for full and deficit irrigation is improving by using subsurface trickle irrigation about $6.6 \%$ compared with surface trickle irrigation. This may be due to the high soil moisture content under SSTI compared with STI. These results are in agreement with those obtained for surface and subsurface trickle irrigation by other authors (El-Gindy and El-Araby, 1996; Machado et al., 2003; Amor and Amor, 2007). The study reveal that tomatoes yield under surface and subsurface trickle irrigation decreased with water stress and this is in agreement with the findings of some studies on the response to water stress of tomato (Topcu et al., 2007; Kebebew and Tilahun, 2010; Hassan and Abuarab, 2013; Salghi, et al. 2014). However, the data indicated more clear differences among treatments in surface trickle irrigation (STI) and subsurface trickle irrigation (SSTI). The total fruit yield varied widely (66.0, 64.83, 57.93, and 45.78 $\left.\mathrm{t} \mathrm{ha}^{-1}\right)$ under the STI and (71.88 65.85, 60.68, and 52.20 t ha ${ }^{-1}$ ) under SSTI for (T1, T2, T3 and T4) respectively. The highest yield (66.0 and $71.88 \mathrm{tha}^{-1}$ ) respectively, for STI and SSTI was recorded in the control T1 $(100 \%$ ETc). This result is due to the amount of water added to the first treatment (T1) is larger than the 
amount of water added to the other treatments. This result is in agreement with (Hassan and Abuarab, 2013) the irrigation up to (100\% ETc) gave highest total tomato yields than that obtained under very stressful condition.

On the other hand, results are presented in Table (5) the highest potential reduction in the fruit yield (30.64\% and $27.37 \%$ ) respectively, for STI and SSTI was recorded with the lowest water treatment T4 (55\% ETc). This due to the $\mathrm{T} 4$ was under water stress. These results indicated that the deficit irrigation T4 saved about (39\%) of water. The results showed no significant difference between the $\left(66.0,64.8\right.$ and $\left.65.9 \mathrm{t} \mathrm{ha}^{-1}\right)$ for (T1S, T2S and T2SS) respectively. However, the moderate water level (85\% ETc) resulted in the lowest reduction in the fruit yield $(1.87 \%$ and $8.38 \%$ ) respectively, for STI and SSTI compared with control treatment $(100 \% \mathrm{ETc})$. These results indicated that the moderate irrigation level T2 saved about $12.52 \%$ of water supplied with lowest reduction in fruit yield. This result in agreement with results of soil water content for (T2S and T2SS) where was near the (RAW) line without any serious water stress. This low percentage of water supplied reduction detected under moderate water level treatment is acceptable for the farmer since it was accompanied with saving roughly $12.52 \%$ of applied irrigation water. This finding can support the viewpoint of (Patane et al., 2011) that under water shortage in arid and semi-arid areas, maximizing water use is considered more valuable to the farmer than maximizing crop yield.

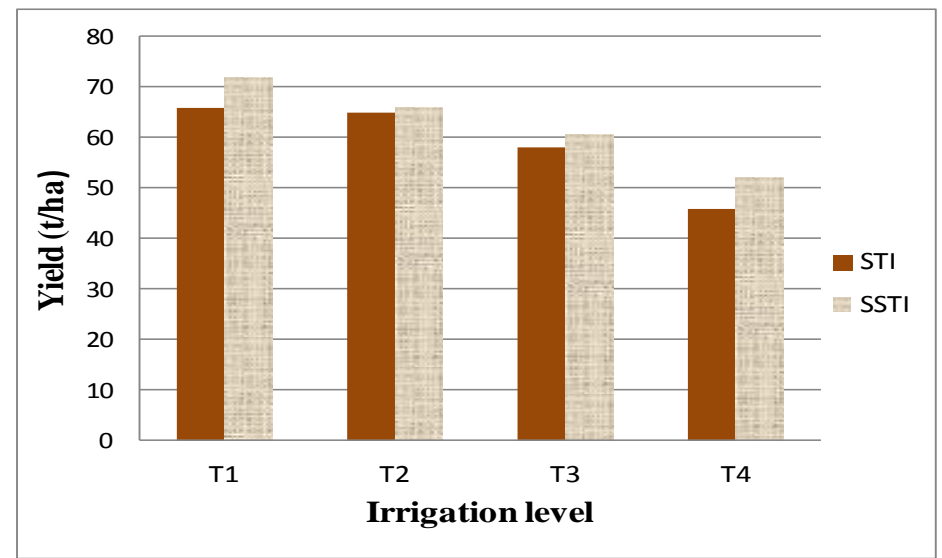

Fig. 2: Average fruits yield for surface and subsurface trickle irrigation system for four irrigation levels. 
Table 2: Comparison of water productivity of irrigation levels for two types of trickle irrigation systems surface STI and subsurface SSTI.

\begin{tabular}{cccccc}
\hline \multirow{2}{*}{ Treat. } & \multirow{2}{*}{$\begin{array}{c}\text { Total water supply } \\
\mathrm{m}^{3} \mathrm{ha}^{-1} \text { season }^{-1}\end{array}$} & $\begin{array}{c}\text { Yield } \\
(\mathrm{t} / \mathrm{ha})\end{array}$ & $\begin{array}{c}\text { IWUE } \\
\left(\mathrm{kg} / \mathrm{m}^{3}\right)\end{array}$ & $\begin{array}{c}\text { Yield } \\
(\mathrm{t} / \mathrm{ha})\end{array}$ & $\begin{array}{c}\text { IWUE } \\
\left(\mathrm{kg} / \mathrm{m}^{3}\right)\end{array}$ \\
\hline T1 & 4530 & $66.0 \mathrm{~b}$ & $14.49 \mathrm{~d}$ & $71.9 \mathrm{a}$ & $15.78 \mathrm{c}$ \\
$\mathrm{T} 2$ & 3510 & $64.8 \mathrm{~b}$ & $16.36 \mathrm{~b}$ & $65.9 \mathrm{~b}$ & $16.62 \mathrm{~b}$ \\
T3 & 2940 & $57.9 \mathrm{~d}$ & $17.19 \mathrm{ab}$ & $60.7 \mathrm{c}$ & $18.01 \mathrm{a}$ \\
T4 & 2370 & $45.8 \mathrm{f}$ & $16.48 \mathrm{~b}$ & $52.2 \mathrm{e}$ & $18.80 \mathrm{a}$ \\
\hline Mean & & $58.63 \mathrm{~B}$ & $16.13 \mathrm{~B}$ & $62.65 \mathrm{~A}$ & $17 . \mathrm{r} \cdot \mathrm{A}$ \\
\hline
\end{tabular}

Table 3: Yield reduction and water saving for two type of trickle irrigation in relation irrigation deficit.

\begin{tabular}{cccc}
\hline \multirow{2}{*}{ Treat. } & \multicolumn{2}{c}{ Yield Reduction \% } & Water saving due to deficit \\
\cline { 2 - 3 } & STI & SSTI & \\
irrigation $\%$ \\
T1 & 0.00 & 0.00 & 0 \\
T2 & 1.78 & 8.38 & 13 \\
T3 & 12.23 & 15.58 & 26 \\
T4 & 30.64 & 27.37 & 39 \\
\hline
\end{tabular}

\subsection{Irrigation Water Use Efficiency (IWUE)}

There was clear interaction between irrigation type and irrigation water level treatments for IWUE (Figure 3). The averages of irrigation water applied under two trickle irrigation systems to tomato crop due to the full and deficit irrigation were $\left(4530,3510,2940\right.$, and $\left.2370 \mathrm{~m}^{3} / \mathrm{h}\right)$ for $(\mathrm{T} 1, \mathrm{~T} 2$, $\mathrm{T} 3$, and T4) respectively. The IWUE value ranged from $14.49 \mathrm{~kg} \mathrm{~m}^{-3}$ to $18.80 \mathrm{~kg} \mathrm{~m}^{-3}$ depending on the interaction treatments. The highest IWUE value was $18.80 \mathrm{~kg} \mathrm{~m}^{-3}$ for SSTI under lowest water level T4 (55\% ETc). While, the lowest IWUE value was $14.49 \mathrm{~kg} \mathrm{~m}^{-3}$ for STI under the highest water level T1 (100\% ETc). Generally, IWUE of the various irrigation level treatments tended to increase with SSTI system compared to STI system irrigation water applied. This result due to the tomatoes yield were higher using subsurface compared to surface irrigation for same water level as shown in (Table 4). This result is in agreement with (Nagaz et al., 2014) the higher water use efficiency was obtained with SSTI as compared with STI system for all irrigation treatments. For irrigation level treatments in general, IWUE values decreased with increasing water level. Water applied in STI was the same as those in SSTI treatment. It is possible to save water improving its use efficiency 
in processing tomato but water should be applied to the crop (85\% ETc), to achieve adequate fruit yield, minimizing fruit losses. These results are in agreement with the previous findings in tomato cultivated under a wide range of deficit irrigation treatments (Ozbahce and Tari, 2010). The amount of water saving due to deficit irrigation is shown in (Table 5). Obviously deficit irrigation saves water but reduces yield. The results suggest that the crop doesn't benefits from the water supplied to fulfill total crop requirement $100 \%$ ETc. These results are in agreement with (Abuarab, et al. 2013 and Hassan and Abuarab, 2013), it is possible to save water improving its use efficiency in tomato to achieve adequate fruit yield. The amount of water saved can be used to provide other areas to increase the tomato yield and consequence increase the IWUE.

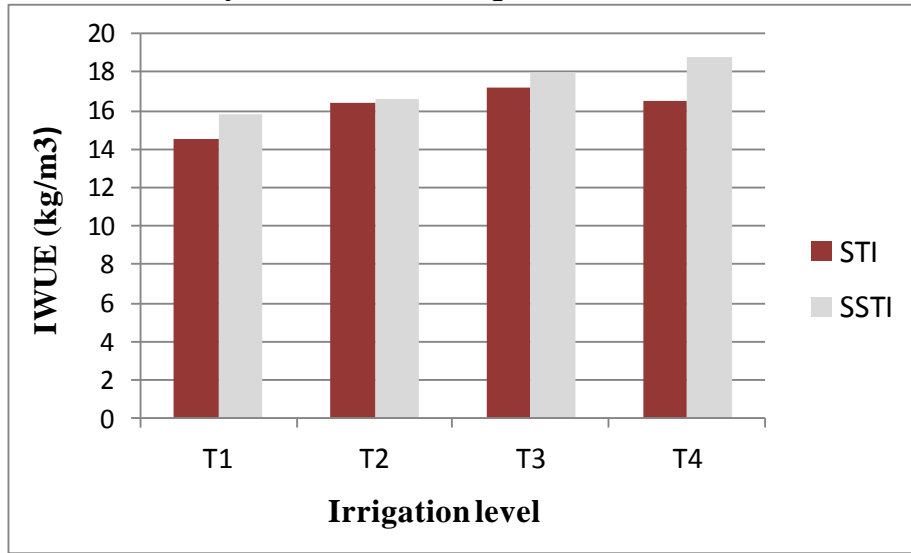

Fig. 3: Irrigation water use efficiency (IWUE) for four irrigation level and two systems of trickle irrigation (STI and SSTI).

\section{CONCLUSIONS}

The experiment was carried out under open field conditions on a clayey soil at the Experimental station, Faculty of Agriculture, Ain Shames University at Shoubra El Khaymah, Qalyubia Governorate, in the winter season 2013/2014, to study the effect of full irrigation and deficit irrigation, using surface and subsurface trickle irrigation on yield of tomato (Solanum lycopersicum. L.) and the irrigation water use efficiency. The experiment was consisted of four irrigation water levels (T1: $100 \% \mathrm{ET}_{\mathfrak{c}}, \mathrm{T} 2: 85 \% \quad \mathrm{ET}_{\mathrm{c}}, \mathrm{T} 3: 70 \% \quad \mathrm{ET}_{\mathrm{c}}$ and $\mathrm{T} 4: 55 \% \quad \mathrm{ET}_{\mathrm{c}}$ ) accompanied with two types of trickle irrigation systems (S: surface and SS: subsurface). Deficit irrigation was applied during the whole growing 
season. The results of this study showed that: 1) a full irrigation (100\% ETc) is required to maximize yield in tomato cultivated in arid climate conditions, 2) the tomato yield was higher using subsurface trickle irrigation compared to surface trickle irrigation for fully and deficit irrigation, 3) the average of tomato yield for fully and deficit irrigation is increased by using subsurface trickle irrigation about $6.6 \%$ compared with surface trickle irrigation, 4) the higher irrigation water use efficiency was obtained with SSTI as compared with STI system for all irrigation treatments, and 5) the moderate irrigation level T2 saved about $12.52 \%$ of water supplied with lowest reduction in fruit yield $(1.87 \%$ and 8.38) respectively for (STI and SSTI).

Therefore, the T2 $(85 \%$ ETc) treatment for two trickle irrigation systems (STI and SSTI) could be considered more applicable and helpful for farmers to optimize IWUE by saving water with lowest reduction in total fruit yield. On the other hand, the amount of saved water increased by deficit irrigation treatments, for T4 $(55 \% \mathrm{ETc})$ producing about $69.4 \%$ of total fruit yield under STI led to save $39 \%$ of irrigation water, while under SSTI producing about $72.3 \%$ of the total fruits yield saved same quantity of irrigation water. The adoption of DI strategies where a 55\% reduction of ETc restored is applied for the whole growing season could be suggested, especially in areas such as those of the Arab region, where water resources are increasingly scarce. Deficit irrigation could be a feasible irrigation technique for tomatoes production where the benefit from saving large amounts of water outweighs the decrease in total yield. However use subsurface trickle irrigation it was most benefit to maximize irrigation water use efficiency compared to surface trickle irrigation. Finally, in conclusion, under conditions of water scarcity, especially in the Arab region, which suffers from water scarcity, subsurface trickle irrigation technologies together with deficit irrigation strategies can be used in order to improve irrigation water use efficiency and tomato yield under open field condition.

\section{REFERENCES}

Abuarab, M. E.; M. M. Shahien and A. M. Hassan. 2013. Effects of regulated deficit irrigation and phosphorus fertilizers on yield, 
water use efficiency and total soluble solids of tomato ASABE Meeting Presentation Paper Number: 1559786:2-16.

Allen, R. G.; L. S. Pereira; D. Raes and M. Smith. 1998. Crop evapotranspiration: Guidelines for computing crop water requirements. Irrigation and Drainage Paper No. 56. FAO, Rome, Italy, $300 \mathrm{p}$.

Andreas, P. S. 2002. Localized irrigation system planning, design, operation and maintenance; FAO Irrigation Manual Module 9:1-81

Amor, M. A. and F. M. Amor. 2007. Response of tomato plants to deficit irrigation under surface or subsurface drip irrigation. Journal of Applied Horticulture. 9(2): 97-100.

Ali, M. A.; M. R. Hoque; A. A. Hassan and A. Khair. 2007. Effects of deficit irrigation on yield, water productivity, and economic return of wheat. Agric. Water Manage. 92:151-161.

ASAE Standards. 2006. Design and installation of microirrigation systems ASAE, EP405.1 FEB03: 942-946.

Battilani, A.; M. Henar Prieto; C. Argerich; C. Campillo and V. Cantore. 2012. Tomato. In: Steduto, P.; Hsiao, T.C.; Fereres, E. and Raes, D. (Eds.), Crop yield response to water. FAO, Irrig. and Drain. Paper 66. FAO, Rome: 192-198.

Benton, J. 2008. Tomato plant culture: in the field, greenhouse, and home garden. By Taylor and Francis Group, LLC. PP: 81-86.

Bhattarai, S. P.; D. J. Midmore and L. Pendergast. 2008. Yield, water-use efficiencies and root distribution of soybean, chickpea and pumpkin under different subsurface drip irrigation depths and oxygation treatments in vertisols. Irrigation Science 26: 439-450.

Douh, B.; A. Boujelben; S. Khila and A. Bel Haj Mguidiche. 2013. Effect of subsurface drip irrigation system depth on soil water content distribution at different depths and different times after irrigation. Larhyss Journal, ISSN 1112-3680, No. 13: 7-16.

EI-Awady, M. N., M. F. Abd-El Salam, M. M. EI-Nawawy and M. A. EI Farrah. 2003. Surface and subsurface irrigation effects on Spinach and sorghum. The II $^{\text {th }}$ Annual Conference of Misr Society of Agric. Eng. Oct. 2003: 118-130.

El-Gindy, A. M. and A. M. El-Araby. 1996. Vegetable crops to 
response to surface and subsurface drip under calcareous soil. Proc. Int. Conf. on Evapotranspiration and Irrigation Scheduling: 10211028.

English, M. J. and S. N. Raja. 1996. Perspectives on deficit irrigation. Agricultural Water Management, Vol. 32, No. 1: 1-14.

Fereres, F. and M. A. Soriano. 2007. Deficit irrigation for reducing agricultural water use. Journal of Experimental Botany, Vol. 58, No. 2: 147-159.

Gomez, K. A. and A. A. Gomez. 1984. Statistical procedures for agricultural research, $2^{\text {nd }}$ ed. John Wiley and Sons, New York, NY, USA.

Hartz, T. and B. Hanson. 2009. Drip irrigation and fertigation management of processing tomato. Vegetable research and information center, University of California, Davis: 1-11.

Hassan, A. M. and M. E. Abuarab. 2013. Effect of deficit irrigation water on the productivity and characteristics of tomato. Misr J. Ag. Eng., 30(2):403-424.

Howell, T. A. 2002. Irrigation efficiency. In Encyclopedia of Soil Science: $736-741$.

Ismail, S. M. 2010. Influence of deficit irrigation on water use efficiency and bird pepper production (Capsicum annuиm L.). Met. Env. and Arid Land Agric. Sci, 21(2):29-43.

Jones, H. G. 2004. Irrigation scheduling: advantages and pitfalls of plant-based methods. Journal of Experimental Botany, 55(407): 2427-2436.

Kang, S. Z. and J. H. Zhang. 2004. Controlled alternate partial rootzone irrigation: Its physiological consequences and impact on water use efficiency. Journal of Experimental Botany, 55: 2437-2446.

Karam, F.; M. Randa; T. Sfeir; M. Oussama and R. Youssef. 2005. Evapotranspiration and seed yield of field grown soybean under deficit irrigation conditions. Agric. Water Manage. 75: 226 - 244.

Kebebew, B. and K. Tilahun. 2010. Fruit yield and quality of dripirrigated tomato under deficit irrigation, AJFAND Vol. 10 No. 2: 2139-2151.

Keller, J. and D. Karmeli. 1975. Trickle irrigation design parameters. 
Trans. of ASAE, 17(4): 678-684.

Kirda, C., 2002. Deficit irrigation scheduling based on plant growth stages showing water stress tolerance. In deficit irrigation practices. C. Kirda; P. Moutonnet; C. Hera and D. R. Nielsen (eds).Water Report No. 22, FAO, Rome, 109 p.

Machado, R. M. A.; M. Rosario; G. Oliveira and C. A. M. Portas. 2003. Tomato root distribution, yield and fruit quality under subsurface drip irrigation. Plant and Soil, Vol. 255, Issue 1:333341.

Nagaz, K.; F. El-Mokh; M. M. Masmoudi and N. B. Mechlia. 2014. Effects of surface and subsurface drip irrigation regimes with saline water on yield and water use efficiency of potato in arid conditions of Tunisiai Journal of Agriculture and Environment for International Development - JAEID, 108 (2): 227 - 246.

Nuruddin, M. M.; C. A. Madramootoo and G. T. Dodds. 2003. Effects of water stress at different growth stages on greenhouse tomato yield and quality. Hort Science, 38: 1389-1393.

Oktem, A.; M. Simsek and A. G. Oktem. 2003. Deficit irrigation effects on sweet corn (Zea mays saccharata Sturt) with drip irrigation system in a semi-arid region. I. Water-yield relationship. Agric. Water Manage, 61: 63-74.

Oliveira, M. R. G.; A. M. Cataldo and C. A. M. Portas. 1996. Tomato root distribution under drip irrigation. J. Amer. Soc. Hort. Sci. 121(4):644-648.

Ozbahce, A. and A. F. Tari. 2010. Effects of different emitter space and water stress on yield and quality of processing tomato under semiarid climate conditions. Agric. Water Manage. vol. 97, issue 9: 1405-1410.

Patane, C.; S. Tringali and O. Sortino. 2011. Effects of deficit irrigation on biomass, yield, water productivity and fruit quality of processing tomato under semi-arid Mediterranean climate conditions. Sci. Hort., 129:590-596.

Perry, C.; P. Steduto; R. G. Allen and C. M. Burt. 2009. Increasing productivity in irrigated agriculture: Agronomic constraints and hydrological realities. Agric. Water Manage. Vol. 96, No. 11:1517- 
1524.

Phene, C. J. 1995. The sustainability and potential of subsurface drip irrigation. In: Microirrigation for a Chaning World, Eds F. R. Lamn. Orlando, Florida, USA: 359-367.

Salghi, R.; S. M. Alaoui; M. Ayoub; A. Abouatallah and S. Jodeh. 2014. Impact of drip irrigation scheduling on yield parameters in tomato plant (Lycopersicon esculentum Mill.) under unheated greenhouse. Int. J. Chem. Tech. Res., 6(7): 3733-3741.

Shahein, M. M.; M. E. Abuarab and A. M. Hassan. 2012. Effects of regulated deficit irrigation and phosphorus fertilizers on water use efficiency, yield and total soluble solids of tomato. AmericanEurasian J. Agric. and Environ. Sci., 12 (10): 1295-1304.

Simonne, E.; R. Hochmuth; J. Brem; W. Lamont; D. Treadwell and A. Gazula. 2012. Drip irrigation system for small conventional vegetable farms and organic. Vegetable Farms University of Florida IFAS Extension HS1203.

Smith, M. and P. Steduto. 2012. Yield response to water: the original FAO water production function. FAO Irrigation and Drainage, paper No. 66, FAO: Rome, Italy ISBN 978-92-5-107274-5:6-12

Topcu, S. C.; Y. Kirda; H. Dasgan; M. Kaman; A. Yazici and M. A. Bacon. 2007. Yield response and $\mathrm{N}$-fertilizer recovery of tomato grown under deficit irrigation. Europ. J. of Agron. 26: 64-70.

الملخص العربى

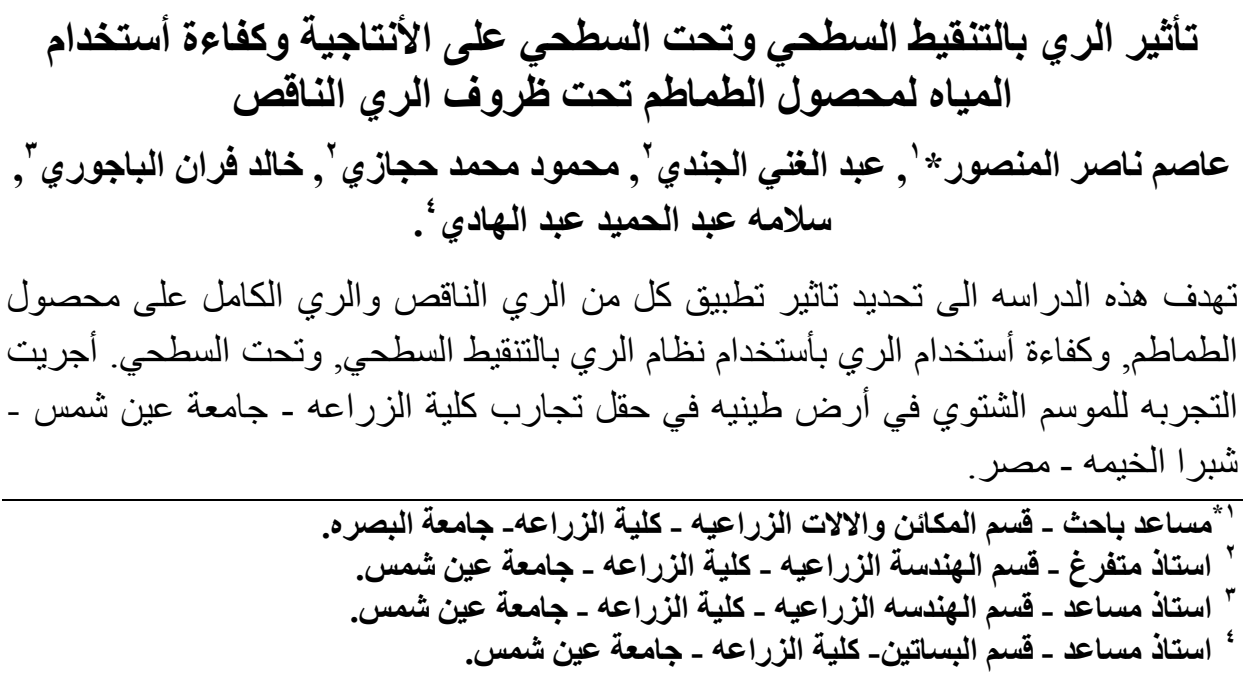


أستخدم تصميم القطاعات المنشقه كاملة العشوائيه, وباربع مكررات. الاحتياجات المائيه البوميه

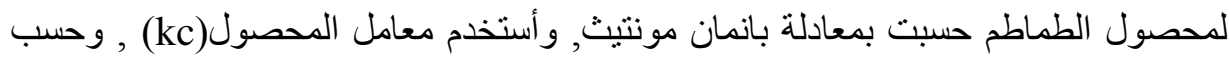

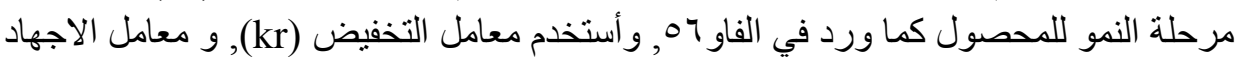

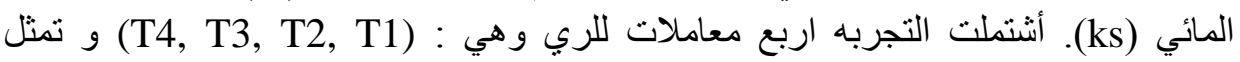

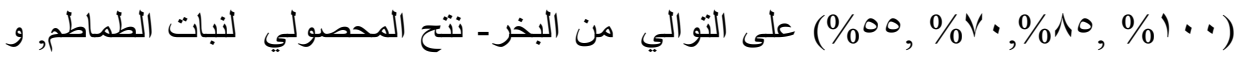
أستخدم نوعين لنظام الري بالتنقيط (السطحي وتحت السطحي) وكان الري الناقص للموسم

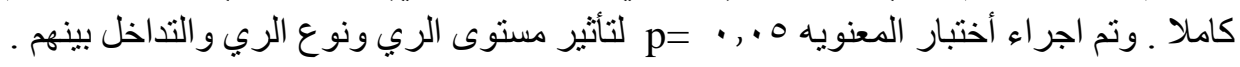

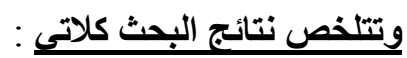

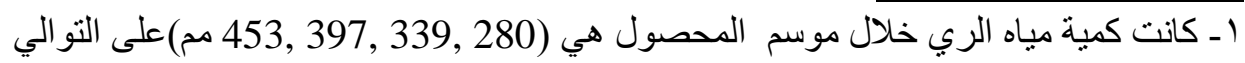
للمعاملات (T1:100\%ET r- كان لمستويات الري, ونوع الري تاثثر بالمحتوى الرطوبي بالتربه في مراحل نمو

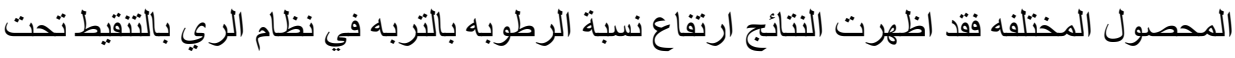

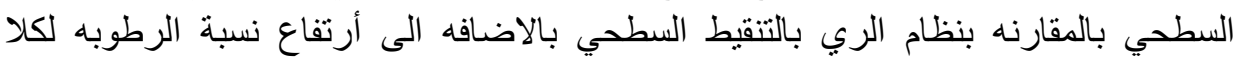

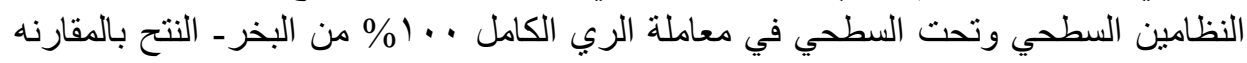

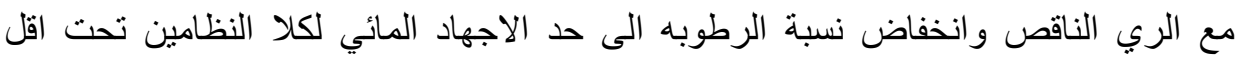

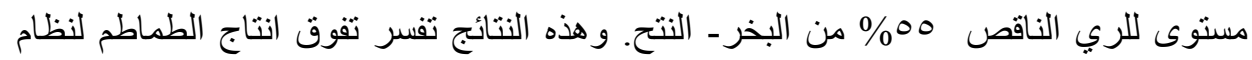
الري بالتنقيط تحت السطحي و الري الكامل على نظام الري بالتنقيط السطحي و الري الري الناقص. بـ هناك تفوق معنوي بالانتاج للري تحت السطحي على الري السطحي. وبلغت منوسط الزيادة

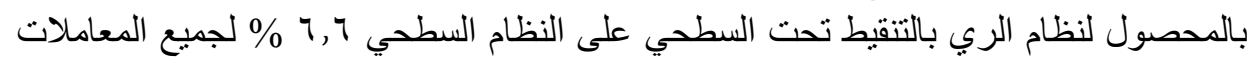

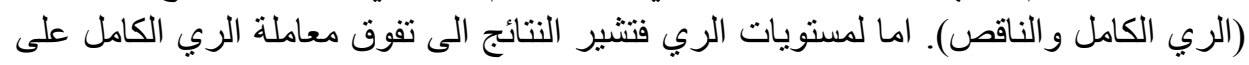

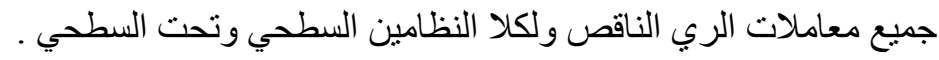
ع أزدياد في كفاءة أستخدام المياه مع انخفاض مستوى الري الري لكل من الري بالتنقيط السطحي وتحت السطحي وقد أظهر نظام الري بالتنقيط تحت السطحي تفوق معنوي بكفاءة أستخدام ماء الري على نظام الري بالتنقيط السطحي.

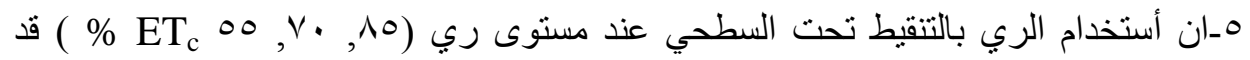

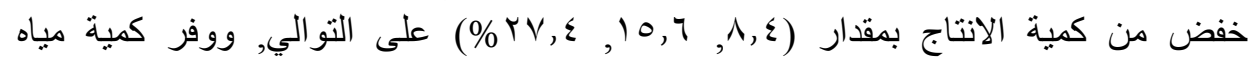

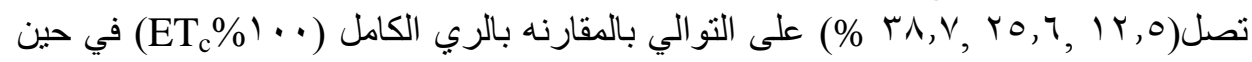

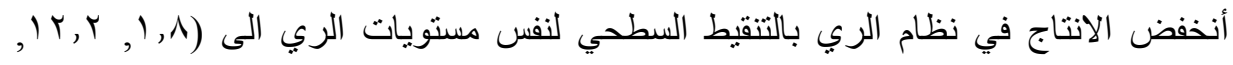

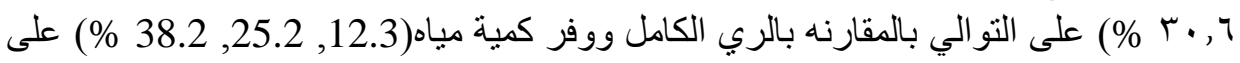
التو الي و هذه الكمية من المياه الموفره ممكن أستخدامها في زر اعة مساحات جديده لزيادة الانتاج وزيادة كفاءة أستخدام مباه الري. وفي الختام في ظل ظروف ندرة المياه خصوصا في المنطقه العربيه التي تعاني من شحه في

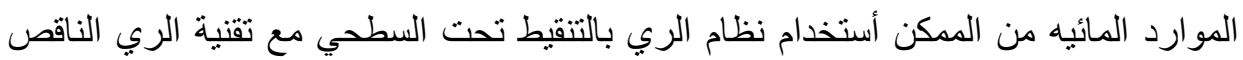

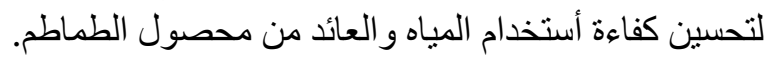

